\title{
TRADE SECRETS OF PATENT
}

\author{
RUDIYANTO \\ 15500068 \\ Fakultas Komputer, 448757187 \\ $\underline{\text { Rudiyanto.student@umitra.ac.id }}$
}

\begin{abstract}
Trade Secret is information that is not known by the public in the field of technology and / or business, has economic value because it is useful in business activities, and is kept confidential by the owner of the Trade Secret. If a leak occurs, it will harm the company, so viewed from a legal and economic standpoint, Trade Secrets are an essential factor for the development of the company. Therefore, legal protection against Trade Secrets is an absolute requirement and is a very important factor especially to prevent unfair business competition from other business people. The research method uses an empirical juridical method, namely by conducting field research to obtain an overview relating to legal protection of trade secrets.
\end{abstract}




\section{A. INTRODUCTION \\ QUIZ Selected Section Class Secret Trade Patent.}

\section{A. UNDERSTANDING TRADE SECRETS}

As stated in Article 1 of the Trade Secret Law (Law Number 30 of 2000), Trade Secret is information that is not known by the public in the field of technology and / or business, has economic value because it is useful in business activities, and is kept confidential by the owner of the Trade Secret. In Article 2 of the Trade Secret Law, it is further explained that the scope of trade secret protection is a production method, processing method, sales method or other information in the field of technology and / or business that has economic value and is not known to the general public. As for what is included in the information technology, are as follows:

$>$ Information about research and development of a technology;

$>$ Information about production / process; and
Information regarding quality control.

While what is meant in business information, is as follows:

Information relating to the sale and marketing of a product;

$>$ Information relating to subscribers;

$>$ Information about finance; and

$>$ Information about administration.

This HKI regime is one of the right ways to protect ideas, besides Patents. Some of the reasons / advantages of applying a Trade Secret to Patents are that intellectual work does not meet patent requirements, the protection period is unlimited, the protection process is not as complicated and expensive as patents, scope, and wider geographical protection.

\section{Trade Secret Protection System}

Trade secrets are protected if the information is confidential. It is only known by certain parties not in general by the community. It has economic value if it can be used to 
carry out commercial activities or businesses or can increase economic profits. Confidentiality is maintained if the owner or parties control have taken appropriate and appropriate steps. , except for the trade secret license granted. The Trade Secret License must be registered with the Directorate General. HKI - DepkumHAM. There is a difference between the other IPRs which are:

Other forms of IPR are not confidential, other IPRs get protection because they are a kind of wealth owned by others.

$>$ Trade secrets get protection even though they do not contain the value of creativity or new thinking. The most important thing is that the trade secret is not generally known. For example, an effective work system.

Other forms of IPR always have certain forms that can be written, drawn or recorded exactly in accordance with the registration requirements set by government agencies.

\section{Period of Protection of Trade Secrets}

With the element of confidentiality in a trade secret, it causes trade secrets to have no protection period, because the most important thing is as long as the owner of the trade secret continues to make efforts to maintain the confidentiality of the information, the information is still protected by trade secrets.

Based on the Trade Secrets Act Article 5 paragraph (1) also stated, that the owner of trade secrets can transfer his rights to other parties through the methods stipulated in the law, namely through inheritance, grants, wills, written agreements, and causes. other reasons that are justified by law (for example, through court decisions that require the owner of a trade secret to disclose information). And specifically for the transfer of rights on the basis of the agreement, it is necessary to have a transfer of rights based on the making of a deed, especially an authentic deed. On the other hand the owner of a trade secret can also transfer his rights through a license agreement. This 
agreement is only granted for a certain period of time with limited rights for licensees. Restrictions are carried out because in practice the owner of a trade secret only gives licenses to other parties and does not mean they will open up all the information they have.

\section{Confidential Contract}

Confidential contract, is a relationship that gives rise to an obligation on one party to keep information learned or received or that is known from within the relationship (confidential re $\neg$ lation ship) and this confidential information is considered as an intangible sheltered object (intangible). If the obligation to circumcise is then not fulfilled and intentionally or unintentionally discloses or uses that information, then the recipient of this information will be considered as breach of confidential (violation of the obligation to keep it confidential) or breach of fiduciary obligatory (violation of trust that becomes an obligation) or breach of contract (violation of contract), which is a violation of trade secrets and can cause harm to the owner.

\section{B. ELEMENTS OF TRADE SECRETS1.}

\section{Information that is not known to} the public in the field of technology and / or business.

Not every information can be interpreted as a trade secret but must be information in the field of technology and or business. This means that the information on employee salaries and matters outside the business and / or technology fields is not the scope of the Trade Secret Law. While the scope of information technology can cover a very wide range, such as the method, composition, operation of the machine etc. Likewise, businesses also have very broad coverage among examples of unique marketing methods, customer lists, supplier lists etc.

\section{Has economic value because it is} useful in business activities.

Economic value arises from information because in that 
information can be used in business activities so that other parties if they know the information can use it for business activities or increase business activities of competitors. This economic value is often identified with competitive power.

\section{Kept confidential by the owner} of the trade secret.

Although an information has fulfilled an element of information that is not known to the public in the field of technology and / or business and has economic value because it is useful in business activities, it is not enough to make an information protected by the Trade Secrets Act. trade secret. These steps must be appropriate and appropriate as stated in article 3 of the Trade Secret Law that there should be appropriate efforts. The Trade Secret Law itself does not regulate in detail about these methods. The author believes that there are at least 2 ways outlined in the protection of trade secrets:

1. Protection efforts from parties outside the company.
2. Protection efforts from parties within the company.

The above must be done because remembering the occurrence of violations of the right to trade secrets does not only occur because of outside parties who are interested but also internal parties such as employees for the purpose of making similar business by utilizing the trade secrets of the company where he works. These two things are not closed, therefore they need to be anticipated so that they do not happen to the disadvantaged parties.

\section{CASE STUDY OF TRADE SECRETS}

Trade secret dispute that occurred between PT. General Food Industries with its two former employees who started from both of their former employees who changed jobs at a rival company PT. GFI. The two employees created a product that was the same as what he did in his previous place of work. After knowing this, the general food PT filed a lawsuit against the two employees and also PT. GFI. 


\section{Discussion:}

Trade secrets are a branch of Intellectual Property Rights law. Trade secret law has a very important role because every business actor certainly does not want the secret of its business activities to be exposed, especially from its business competitors, and which is protected by trade secret law is a secret in the business world that has economic value and is not known to the public. Trade secrets are regulated in Law No.30 of 2000 concerning Trade Secrets. In a business activity there must be things that can cause a dispute. One dispute can occur due to a violation of trade secrets.

The public prosecutor charged the two employees with violations of trade secrets and the judge sentenced the two employees to two months in prison. The two convicts were considered to have violated Article 17 of Law No.30 of 2000 concerning Trade Secrets, namely that "without the right to use trade secrets of other parties". In fact, the authors see that the two convicts did not violate trade secrets, because PT. GFI does not clearly state what are the secrets of the company. So according to the authors concluded that what was alleged was not a secret so that the two convicts should have appealed.

\section{RIGHT OF THE SECRET OWNER}

\section{Using his own trade secrets.}

As we know, trade secrets are one of the intangible assets in which they have benefits and attach to them in ownership. So from here it can be assumed that intangible assets related to trade secrets are similar to tangible objects in which the owner has the right to use and use them to take advantage of these assets freely as long as they do not violate the law and the public interest.

Property rights are absolute to the owner, which also applies to intellectual property rights, especially trade secrets. However, the privilege of trade secrets as an intangible asset, has protection with an unlimited period of time as long as it fulfills the elements of trade secrets that are protected by law. So that it affects the 
rights of owners who can take advantage of trade secrets as long as they fulfill the trade secret elements that are protected by trade secret laws, namely information that is not known to the public in the field of technology and / or business has economic value because it is useful in business activities, and kept confidential by the owner of a trade secret.

\section{Give licenses or prohibit other} parties from using trade secrets or disclosing trade secrets to third parties for commercial purposes.

Intangible assets and intangible assets related to trade secrets also give the owner the right to prohibit other parties from using them or using these trade secrets. Because the use without rights or without permission is classified as a bad action because there is an element of not having good intentions that can harm the owner. The following is also to provide information or disclosure actions by other parties because it is dangerous for the trade secret itself because if it is known by the general public it results in the loss of trade secret protection.

\section{B. CONCLUSION}

Trade Secret is information that is not known by the public in the field of technology and / or business, has economic value because it is useful in business activities, and is kept confidential by the owner of the Trade Secret. If a leak occurs, it will harm the company, so viewed from a legal and economic standpoint, Trade Secrets are an essential factor for the development of the company. Therefore, legal protection against Trade Secrets is an absolute requirement and is a very important factor especially to prevent unfair business competition from other business people. And trade secrets are protected if the information is confidential. It is only known by certain parties not in general by the community. It has economic value if it can be used to carry out commercial activities or businesses or can increase economic profits. Confidentiality is maintained if the owner or parties are mastering it has taken decent and 
appropriate steps., except for the trade secret license granted.

\section{ACKNOWLEDGEMENT}

University Of Indonesia

University Of Mitra Indonesia

Telkom University

University Of Mellbourne

Saitama University

\section{REFERENCE (Based ISO 690 )}

[1] A. S. Putra And O. M. Febriani, "Knowledge Management Online Application In Pdam Lampung Province," In Prosiding International Conference On Information Technology And Business (Icitb), 2018, Pp. 181-187.

[2] A. S. Putra, O. M. Febriani, And B. Bachry, "Implementasi Genetic Fuzzy System Untuk Mengidentifikasi Hasil Curian Kendaraan Bermotor Di Polda Lampung," J. Sist. Inf. Dan Manaj. Basis Data, Vol. 1, No. 1, Pp. 21-30, 2018.

[3] O. M. Febriani And A. S. Putra, "Sistem Informasi Monitoring Inventori Barang Pada Balai Riset Standardisasi Industri Bandar Lampung," J. Inform., Vol. 13, No. 1, Pp. 90-98, 2014.

[4] Putra, Arie Setya. "2018 Artikel Struktur Data, Audit Dan Jaringan Komputer." (2018).

[5] Putra, A. S. (2018, July 17). Paperplain Fundamental Create Application With Borland Delphi 7.0 University Of Mitra Indonesia. Retrieved From Osf.Io/Pbrn9. 


\section{E. REFERENCE (Based APA)}

Putra, A. S., Aryanti, D. R., \& Hartati, I. (2018, November). Metode SAW (Simple Additive Weighting) sebagai Sistem Pendukung Keputusan Guru Berprestasi (Studi Kasus: SMK Global Surya). In Prosiding Seminar Nasional Darmajaya (Vol. 1, No. 1, pp. 85-97).

Sari, D. P., Febriani, O. M., \& Putra, A. S. (2018, November). Perancangan Sistem Informasi SDM Berprestasi pada SD Global Surya. In Prosiding Seminar Nasional Darmajaya (Vol. 1, No. 1, pp. 289-294).

Putra, A. S. (2018). Paperplain: Execution Fundamental Create Application With Borland Delphi 7.0 University Of Mitra Indonesia.

Putra, A. S., Sukri, H., \& Zuhri, K. Sistem Monitoring Realtime Jaringan Irigasi Desa (JIDES) Dengan Konsep Jaringan Sensor Nirkabel. IJEIS (Indonesian Journal of Electronics and Instrumentation Systems), 8(2), 221232.

Darmawan, A., Yuliawati, D., Marcella, O., \& Firmandala, R. (2016). Sistem Absensi dan Pelaporan Berbasis Fingerprint dan SMS Gateway. EXPLORE, 7(1).

Febriani, O. M., Wahyuni, T., \& Yusuf, S. (2017). DESIGN OF WEBSITE-BASED INFORMATION SYSTEM FOR EDOCUMENT ADMINISTRASI IN THE COMMUNITY SERVICE UNIT (A Case Study at Rajabasa District). INTERNATIONAL JOURNAL OF
COMPUTERS \& TECHNOLOGY, 16(7), 7010-7020.

Febriani, O. M., \& Wahyuni, T. (2017, October). PERANCANGAN SISTEM E-DOCUMENT ADMINISTRASI LOGBOOK PENELITIAN PADA UNIT LAYANAN DI BANDAR LAMPUNG. In Prosiding Seminar Nasional Darmajaya (Vol. 1, No. 1, pp. 187-194).

Febriani, O. M., \& Permadi, A. B. (2017). Implementasi Sistem Aplikasi Data Bimbingan dan Pelanggaran Siswa pada Sekolah Menengah Atas di Lampung Tengah dengan Metode Analisis dan Desain Sistem Terdistribusi (SSAD). EXPERT, 7(1).

Febriani, O. M., \& Ambarwati, L. (2015). PERANCANGAN APLIKASI PENGOLAHAN DATA PENJUALAN UKM KELANTING KHAS TELO DESA SIDOHARJO KECAMATAN JATI AGUNG KABUPATEN LAMPUNG SELATAN. Jurnal Teknologi Informasi dan Bisnis Pengabdian Masyarakat Darmajaya, 1(1), 77-95.

Febriani, O. M. (2015). Rancang Bangun Aplikasi Ecommercemenggunakan Freewebstore pada UKM Kelanting di Desa Sidoharjo Lampung Selatan. Prosiding Sembistek 2014, 1(02), 446-458. 